\title{
Collusion between politicians and journalists in the context of wiretapping of journalists
}

\begin{abstract}
This case study reports about the collusion scandal behind the widespread wiretapping operations of various journalists. The report, however, focuses mainly on one part of the affair, namely the clear collusion between a journalist from the daily Pravda, and a top politician - a Member of Parliament, whose conversations were also recorded. MP Robert Kaliňák was apparently trying to persuade the reporter Vanda Vavrová to publish discrediting material about his political rival. The study thus largely examines the media's role in politics and ethical issues resulting from trespass of the journalistic agency for objective and impartial reporting. Moreover, initial coverage of this affair by the selected media is analysed throughout the study to pinpoint the role of Slovak journalists/media while facing the controversial behaviour of one of their peers. It was found that the media actually underplayed the collusion story and focused their attention mostly on the wiretapping affair, strongly condemning the actions by the state authorities. Ironically, a few years later it was proved that the wiretapping of journalists (in contrast to other persons and institutions) was both legal and justified. Moreover, the media ignored the possible political and criminal corruption issues behind the double scandal.
\end{abstract}

Key words: wiretapping, collusion, Slovakia, Pravda, ethics

\section{Introduction $^{1}$}

$\mathrm{R}$ elatively few publicly-known cases in which the most popular commercial media have uncritically supported politicians or political parties have occurred in recent years in Slovakia. In general, the major media in the country strive to show their independent stance vis-a-vis politicians

1 The paper was written with a contribution by Alena Ištoková, L'ubica Adamcová and Veronika Džatková. Internal reviews were conducted by Jozef Hajko and Juraj Filin. Research activities were financed by the European Union: ANTICORRP (Grant agreement no: 290529) and supplementary grant from the Slovak Research Agency (grant agreement DO7RP-0039-11). 
and political parties (for recent negative examples see MEMO98, 2016 and TIS, 2016). Although many cases of particular utilisation of public media as a form of propaganda machine were reported in the 1990s, major collaboration between the media and politicians in power slowly evaporated from 2000 onwards. This was mainly due to the de-politicisation of a previously extremely politically polarised society and, at the same time, commercialisation of the media, and partly due to the growth of modern ICT and generally accessible alternative sources of information on the Internet or in cable/satellite broadcast. The ICT also made it possible to make public information that otherwise would be difficult to publish in the media, due to fears of expensive libel cases. This issue also was behind this case, as well as behind an even more explosive corruption case a month later. ${ }^{2}$ Yet, it should be noted here that new local media owners seem to get involved in the media business not only for profit making (Kernová, 2015).

In general, the ethical-professional guidelines of journalists explicitly demand a high level of impartiality and balance. ${ }^{3}$ Therefore, although it is more likely to be accepted when the media as institutions show a certain tacit bias towards certain politician or a political party, it is much more difficult to accept such bias, or, indeed, collusion (defined as the dynamics of everyday interaction between politicians and journalists which occurs when these interactions threaten or subjugate the operational autonomy of the media to political requirements), in the case of individual journalists in key news media. The occasional cases where media or journalists appear to secretly collaborate with politicians thereby have the potential to become major political and media scandals. This case study reports on the unethical cooperation (collusion) between the then Member of the Slovak Parliament Robert Kaliňák and Vanda Vavrová, a journalist for the daily newspaper Pravda. The controversial case focuses on the attempts by Kaliňák, who was also vice-chairman of the then opposition, leftist political party Smer-SD, to influence journalistic output.

This story is, however, related to the wider problem of illegal wiretapping of various journalists and other public figures either in the context of alleged concern over state security and military secrets, or with reference to the collection of scandalous information concerning political or business opponents. It should be noted here that a journalist from the weekly

${ }^{2}$ See https://en.wikipedia.org/wiki/Gorilla_scandal.

${ }^{3}$ See Code of Ethics of a Journalist, http://trsr.sk/dokumenty/eticky-kodex-novinara-uinny-od-1-1-2011. 
Žurnál, Patrícia Poprocká (Ďurišová), was wiretapped in connection with possible leaks of confidential information by the secret service already in 2007, as Žurnál reported about leaks of classified documents from the Military Counterintelligence Service (MCI). This case happened under the Ministry of Defence (MoD) run by a representative from the SmerSD party (Boyd, 2011). However, no major scandal with political consequences resulted at that time, ${ }^{4}$ although the case was widely discussed in the media. In fact, initially, the editor-in-chief and journalist from the weekly Žurnál received a fine from the National Security Authority which was later cancelled by the Supreme Court. Moreover, as stated by former Minister of Defence Lubomír Galko, wiretapping operations have been regarded as standard operations by Military Defence Intelligence (MDI) or by MCI under any government (Galko, 2011). Yet, as will be shown, the wiretapping operation actually downplayed the collusion case, as well as possible corruption case(s) at the MoD.

\section{The role of the media in a liberal democracy}

One of the fundamental features of a liberal democratic political system is the existence of free and independent media. The key political roles of the media include providing information, checking the accountability of public figures and authorities, and creating a space for public debate. However, the media can also represent vested interests. Collusion seems to be occasionally present even in the leading agenda setting newspapers (Greenwald, 2012). Some also argue that collusion is rather typical of the whole media sector in some countries (Oborne, 2012; Orme, 1997), while others document collusion in the particular field of business and financial journalism (Butterick, 2015). A recently hyped case from Hungary, where the executive director of Hir $T V$, the cable news channel, openly admitted previous long-term, behind the scenes cooperation with the ruling government (Adam, 2016), ${ }^{5}$ can serve as a perfect example of large-scale collusion in practice.

The other part of the story concerns wiretapping operations focused on journalists. Is this activity, if focused on journalists/media, always illegal in a liberal democracy, as suggested by the then Prime Minister Iveta Radičová?

${ }^{4}$ See http://www.visegradgroup.eu/news/ex-slovak-defence.

${ }^{5}$ For the original transcript of the interview see: https://www.mediapiac.com/mediapiac/Tobb-nezo-jott-mint-ment/112473/. 
In order to identify whether the media are fulfilling their expected positive political functions, one of the founders of communications studies, Harold Lasswell, devised the famous Lasswell Formula, which suggests that a convenient way to analyse an act of communication is to answer the following questions: Who Says / What / In Which Channel / To Whom / With What Effect? Although this analytical approach seemed to be particularly applicable to the study at first, the research itself has revealed a complex, multilayered structure of political-media communication in this case. Therefore, this rather simplistic and linear model had to be abandoned as an analytical method. Yet the elementary structure of the formula has been maintained within the framework, due to its explanatory effectiveness in contrast to the complex phenomenon of underlying noise in the studied case.

Regarding the more complex and current analytical approach, Pfetsch (2013) and her colleagues have suggested that collusion has two dimensions. First, and less frequent, is the effect of political orientation, which provides a stronger measure of collusion based on general ideological alignment. Second, and more frequent, is the propensity of politicians to pass on information to journalists with a similar ideological orientation, which should be seen as a measure of strategic and issue-specific collusion (or politicisation).

Based on these two key distinctions, Pfetsch (2013) has defined four specific political communication journalistic cultures. (1) A media driven political communication culture occurs when politicians influence the media agenda weakly, and indirectly (back stage strategies). (2) Strategic political communication culture refers to political influence over the media agenda which is strong, but indirect (e.g. via back stage strategies or via opinion polls). (3) Traditional political communication culture occurs when the media political reporting is under political or economic pressure but with substantial political impact by the media themselves. The politicians maintain pressure on the media without adapting themselves to its requirements. Finally, there is a (4) mixed political communication culture in which neither media nor politics are regarded as dominant.

Considering these categories, it could be said that the Slovak example suggests - if this is seen as a prevailing or representing a more general trend - that a media driven political communication culture occurs in the country. Kaliňák clearly used the backstage strategy of communication with the media to influence his desired agenda, because he had no chance of succeeding in his mission by direct pressure over the daily as a whole. 
However, while considering this case as an exception to the rule (as all reactions suggest), then the mixed political communication journalistic culture is more likely prevailing within the republic.

\section{Control analysis: the background of Pravda daily}

For the purpose of the study, the question of "Who?" has been associated mainly with control analysis. ${ }^{6}$ The daily Pravda has been owned by the Florena company ${ }^{7}$ since 2010 . The business deal was facilitated by the Slovak investment group J\&T (Folentová, 2010), which is in itself an unusual approach, in contradiction with the much cherished transparency of media ownership, as the financial group is seen by some as being linked to the political party Smer-SD. However, these claims are difficult to confirm or dismiss, although some changes in staff and editorial policy were noted shortly afterwards (see Struhárik, 2010).

The Pravda daily has repeatedly defined itself as liberal-left. ${ }^{8}$ In general, its readership represents approximately 7 per cent of the total relevant population.

The actual collaboration between Kaliňák and Vavrová began in 2009 and neither of them has denied that they know each other well. In fact, Vavrová had to leave Pravda in summer of 2009 due to the text message she sent by mistake to her colleague instead of to Kaliňák. The message contained Vavrová's opinion about the internal office affairs (Glovičko, 2011a). However, Vavrová returned to her position during the spring of 2010, when the new editor-in-chief employed her again. ${ }^{9}$

The transcript of one of the wiretapped phone calls, made in July 2011, was published online on $23^{\text {rd }}$ November, 2011. It was also mailed to the editors-in-chief of leading newspapers, including the newspapers Pravda and Nový Čas, as well as the television news channel TA3, which carried the story the next day (see SITA, 2011; TASR, 2011a). This transcript

${ }^{6}$ Who owns this newspaper? What are their aims? What are their political allegiances? Do they attempt to set the editorial policy? Does the fact that they are leftist account for the newspaper's repeated attacks on the right political parties? Are they subject to any kind of legal or ethical constraints? How does the editor decide what to put in the paper?

7 See http://rejstrik-firem.kurzy.cz/28864867/florena-as/.

8 See http://www.pravda.sk/info/7036-o-nas/.

9 See: http://spravy.pravda.sk/autor/128-vavrova-vanda/. 
portrayed a new collusion between Vavrová and Kaliňák. The problem of the influence of vested interests on the media or journalists in Slovakia is not new, and journalists themselves report about occasionally occurring pressures from individuals or institutions in various state and private sectors (see Slovak Press Watch, Mr. THINK \& Donath-Burson-Marsteller, 2008).

\section{Content analysis: recorded conversations between Vavrová and Kaliňák}

The scandal became famous under the nickname used by the politician to address the journalist in their dialogues, Babe. Kaliňák used jovial and informal language in the recorded conversations, as well as vulgarisms with respect to her journalistic colleague (TASR, 2011a). The actual content of the dialogue was mainly focused on a request by Kaliňák to publish news of a rather minor breach of the law committed by an opposition politician, the Minister of Defence (MD) Lubomír Galko (he was apparently driving too fast). Kaliňák also put pressure on Vavrová by emphasising the fact that he was considering stopping divulging secrets to her and turning to another daily - namely the liberal-right SME, the main competitor of Pravda, which would publish the scandalous news more promptly (Czwitkovics, 2011a).

After the transcript of the dialogue between Vavrová and Kaliňák was made public, MD Galko accused Kaliňák of having inappropriate influence over Pravda. In response, Kaliňák blamed Galko for the illegal wiretapping of a private communication between him and Vavrová via the MDI (Kováč, Vargová, 2011).

The controversial information was never published, as the scandal overtook the main reason for Kaliňák’s pressure on Vavrová. Moreover, Nora Slišková, the editor-in-chief of Pravda, resolutely and immediately denied knowing about any close collaboration between Vavrová and Kaliňák (Czwitkowics, 2011b). That was most likely true, by reason that Kaliňák himself complained about a lack of influence on Slišková during the recorded conversations.

The wiretapping affair has, however, documented serious ethical problems concerning the relationship between the media and politicians in Slovakia. Clearly, the trustworthiness of the agenda-setting media as a watchdog of democracy, must be protected. The work of any journalist 
consists of a day-to-day effort to acquire original and valuable pieces of information. Every journalist needs a wide range of contacts to obtain information, including political actors or political insiders. However, one of the most important features of a journalist's work is to analyse and critically assess the truthfulness and motivation of any source.

Finally, the Press $\mathrm{Act}^{10}$ as well as the Code of Ethics of a Journalist guarantee confidentiality of sources. Apparently, it was exactly this issue that made the journalists and media in general (not only Pravda) so furious about the wiretapping operation.

\section{Audience analysis: the secret service materials and influence over the media output}

Örnebring (2012) observed that the media in western societies are in many ways used for communication between elites, and the goal of PR is often communicating with other elites, rather than directly with the general public. Davis (2002) also discussed a number of media practices and uses of media for communication primarily aimed at other elites, so-called eliteto-elite communication. This could be, for example, getting positive media coverage as part of internal party leadership struggles, or blocking public debate (by blocking media access) on strategically problematic and risky political issues. However, for the purpose of this study, probably the most important practice in this kind of media usage is influencing policy decisions by leaking information to either boost one's own side or discredit/ weaken the opposite side in policy conflicts (see Davis, 2002).

In fact, it was argued that the political atmosphere in the country probably helped the case to gain popularity, as well as the tacit influence maybe helped to discredit one side of the conflict rather than other. For example, it is rather questionable and surprising that minister Galko was dismissed so promptly, only one day after the scandal was published, as he actually argued that the case was just a ruse to have him dismissed due to his anti-corruption efforts in the MoD (see Galko, 2011). The political context played role here too. The wiretapping affair erupted a month after the Parliament failed to approve a vote which was connected with a vote of confidence in the government on $10^{\text {th }}$ October, 2011. As a result, the government had to resign. In this vote, Galko's SAS party played a key role.

10 See http://www.culture.gov.sk/ministerstvo/legislativa/pravne-predpisy-v-oblasti-kultury-19b.html. 
The subsequent political grudge between Kaliňák and Galko was closely followed by the media and largely commented by them and other political representatives across the political spectrum. This particular exchange of attempted discrediting practices and mutual accusations via the media is a clear example of elite-to-elite communication. The dominant perception, particularly common among politicians, is that media influence is sought because the media are very powerful in shaping public opinion and they also serve as important tools for elite-to-mass communication (Örnebring, 2012). Therefore, both the mutual accusations between Kaliňák and Galko and the scandal behind the whole case were most likely driven by a combination of elite-to-elite and, less so, elite-tomass communication practices.

\section{Media analysis: the investigation of the wiretapping and the media output}

The transcripts were published in all the leading newspapers. We focused on only three newspapers here: Pravda, the liberal-right SME and the business-economy paper Hospodárske noviny.

The Prosecutor General began an investigation into the case of wiretapping of a journalist on $24^{\text {th }}$ November, 2011. Galko also announced that one employee was responsible for leaking the information from the MDI (SITA \& TASR, 2011). In the summer of 2015, the prosecutor filed a suit against five officers from the MDI for the illegal wiretapping of civilians. They were accused of 18 offences, and altogether of having violated the rights of 13 people (Stupňan, 2015). Galko, a former MoD, was acquitted of illegal actions in this affair and some justification in the reasons given for part of the wiretapping was also acknowledged. Moreover, the results of the investigation published in February 2016 proved that, first, Galko was not legally responsible for any wiretapping, and second, the wiretapping of journalists, in contrast to the wiretapping of other persons, was legal (STV News, $23^{\text {rd }}$ February 2016). It is interesting to note, though, that Pravda published a lead article with this news the next day, but did not mention at all that the wiretapping of the journalists was legal (Pravda, 24 ${ }^{\text {th }}$ February 2016 and online version $23^{\text {rd }}$ February $\left.2016^{11}\right)$. Actually, even when the prosecutor dropped

\footnotetext{
11 http://spravy.pravda.sk/domace/clanok/384524-galkovi-tajni-idu-pred-sud/.
} 
further investigation of this case for the first time in September 2015, especially the part related to the wiretapping of journalists, it received by and large lukewarm attention from the media (see Galko, 2015). This could be only partly explained by the distance from the original event. In other words, for much of the media this news did not fit into their criterion of 'topicality,' although one could also assume that if the results of the investigation had been different, then the media might have increased their interest in it.

Regarding the analysis of the overall media output, the follow up of the case can be considered as relatively highly professionalised. Yet, in general, the media played a questionable role in the wiretapping affair. If the quantitative aspect (the number of published articles related to the controversial case) is taken into account, Pravda most often reported on the wiretapping case. However, this is not surprising, since the daily was dealing with an affair involving one of its own journalists, and the reports mostly carefully avoided elaborating the case of the recorded conversations and focused on the initial wiretapping, with emphasis on the breach of media freedom. In addition, Nora Slišková, the Editor-in-Chief of Pravda, believed that her newspaper was the key target (Slišková, 2011). Apparently, the MDI was curious about the journalist's sources related to the activities of the MoD or MDI (Pravda, 2011b). According to the MDI, there was a potential risk that Vavrová could conduct business with confidential material about the secret service and, moreover, that she communicated with former and contemporary employees of the MDI. However, the publication of the transcripts proved that the conversation between Kaliňák and Vavrová did not contain any potential jeopardy to the national security.

\section{Quantitative analysis of the quality of journalistic work}

For the quantitative analysis of the quality of journalistic work, we established three key qualitative criteria. These criteria are based on the Fundamental Values established in the Journalist's Code of Ethics (article II): impartiality, balance, objectivity, honesty, truthfulness, responsibility and scrupulous fact-checking. However, it would have been difficult to measure these criteria independently, as they are very loosely defined. Therefore we created three categories that can also be empirically analysed: objectivity (includes impartiality, balance, honesty, truthfulness, 
responsibility), verification of facts (includes objectivity, honesty, truthfulness, responsibility and scrupulous fact-checking) and stating sources (includes impartiality, balance, objectivity, honesty, truthfulness, responsibility). Although the Journalist's Code of Ethics actually deals with individuals, we have to assume that the same rules, in the final analysis, apply to news outlets too. First, under objectivity we analysed whether the news outlet provided space to all parties involved. Were there any signs of bias? Second, verification of the facts refers to the whole process of obtaining sources. How did the news outlet verify their information? Usually, the information is verified by the use of at least two mutually independent sources. Were there two sources of information present? Third, news outlets are always (with some legal and ethical exceptions which must be mentioned) obliged to state the source of their information. Did the newspaper mention the sources of information? Where the main source mentioned was a wire agency, we did not expect other sources to be mentioned in the article.

The analysis of the three above mentioned categories was done independently by two researchers, with a third researcher checking and verifying possible inconsistencies. The initial inconsistencies affected about a third of all assessments. The period which was included in the analysis consisted of the first two weeks after the breaking of the scandal.

Moreover, considering that there were actually two events present in many articles (one with emphasis on wiretapping, another one on the unethical behaviour of a journalist), we assessed both events independently. Most articles contained only one aspect, but in some cases a particular article included both parts of the story. In the case of commentaries, these were analysed separately and we focused only on the frames used in these commentaries.

Table 1 below shows the quantitative coverage. Clearly, Pravda devoted the largest attention to the wiretapping/collusion affair(s), especially in commentaries and editorials.

Table 1

Number of articles about wiretapping + collusion

\begin{tabular}{||l|c|c|c|c|c|c||}
\hline & Pravda & \% & SME & \% & HN & \% \\
\hline News articles & 19 & 26 & 17 & 32 & 14 & 38 \\
\hline Editorial, commentary, opinions & 36 & 50 & 17 & 32 & 9 & 24 \\
\hline Articles related to the case & 17 & 24 & 20 & 37 & 14 & 39 \\
\hline Total & $\mathbf{7 2}$ & 100 & 54 & 100 & 37 & 100 \\
\hline
\end{tabular}


In general, Pravda was logically under more moral pressure by its journalistic peers and general public, and that is perhaps why it also offered more analytic and topical news and commentaries to its readers than either Sme or $H N$.

Table 2 shows the results of the analysis of objectivity, verification and sources of information in the case of MDI's wiretapping of journalists.

Table 2

Objectivity, verification, source of information with regard to wiretapping

\begin{tabular}{||l|c|c|c|c|c|c|c|}
\hline & Total & Objectivity & $\mathbf{\%}$ & Verification & $\mathbf{\%}$ & Source & $\mathbf{\%}$ \\
\hline Pravda & 19 & 15 & 79 & 11 & 58 & 18 & 95 \\
\hline SME & 16 & 12 & 75 & 12 & 75 & 16 & 100 \\
\hline$H N$ & 14 & 8 & 57 & 11 & 79 & 14 & 100 \\
\hline
\end{tabular}

Surprisingly, Pravda (almost equally with Sme) was the most objective news outlet regarding the reporting on wiretapping. However, in the case of verification of data, the results were opposite. Finally, sources were correctly mentioned in all the analysed outlets with a minor deviation in the case of Pravda.

Table 3 presents the results of the analysis of objectivity, verification, sources of information in Kaliňák vs. Vavrová collusion. Considering the low number of articles that dealt with this issue, we have come to the conclusion that wiretapping affair actually silenced the issue of unethical journalistic behaviour in the media discourse. In a sense, this was logical, since there was no controversy - all the media condemned this behaviour, including Pravda.

Table 3

Objectivity, verification, source of information with regard to Kaliňák - Baby (Vavrová)

\begin{tabular}{||l|c|c|c|c|c|c|c||}
\hline & Total & Objectivity & $\mathbf{\%}$ & Verification & $\mathbf{\%}$ & Source & $\mathbf{\%}$ \\
\hline Pravda & 2 & 0 & 0 & 1 & 50 & 2 & 100 \\
\hline SME & 2 & 0 & 0 & 1 & 50 & 2 & 100 \\
\hline$H N$ & 1 & 0 & 0 & 1 & 100 & 1 & 100 \\
\hline
\end{tabular}

In the case of missing objectivity, it was probably too demanding to be achieved in every single news report. However, it should be noted here that this dual scandal actually may have also suppressed other issues of 
great importance such as various corruption cases, including, for example, the MOKYS scandal (see Galko, 2011).

Tables 4-5 below show the same content based on the type of media framing. Framing is a way to make sense of reported events by connecting an event with similar facts, interpreting the situation, underlining the atmosphere within which the corruption case takes place, and so on (see Entman, 1993). We used the following categories: positive (1), negative (2), negative and positive (3), neutral (4), impossible to determine (5).

Table 4

Frame with regard to wiretapping

\begin{tabular}{|c|c|c|c|c|c|c|c|c|c|c|c|c|}
\hline & & 1 & $\%$ & 2 & $\%$ & 3 & $\%$ & 4 & $\%$ & 5 & $\%$ & Total \\
\hline \multirow{3}{*}{ News articles } & Pravda & 0 & 0 & 13 & 68 & 2 & 11 & 4 & 21 & 0 & 0 & 19 \\
\hline & SME & 1 & 6 & 2 & 13 & 3 & 19 & 10 & 63 & 0 & 0 & 16 \\
\hline & $H N$ & 0 & 0 & 5 & 36 & 1 & 7 & 7 & 50 & 1 & 7 & 14 \\
\hline \multirow{3}{*}{$\begin{array}{l}\text { Editorial, commen- } \\
\text { tary, opinions }\end{array}$} & Pravda & 2 & 6 & 30 & 86 & 0 & 0 & 2 & 6 & 1 & 3 & 35 \\
\hline & $S M E$ & 2 & 12 & 11 & 65 & 1 & 6 & 1 & 6 & 2 & 12 & 17 \\
\hline & $H N$ & 2 & 25 & 4 & 50 & 2 & 25 & 0 & 0 & 0 & 0 & 8 \\
\hline
\end{tabular}

We can see that there were two dominant frames in news articles in reaction to the wiretapping part of the affairs: either negative - especially in Pravda, or mostly neutral (Sme) and neutral as well as negative $(H N)$. Similarly, framing in commentaries was especially negative in Pravda, followed by Sme and $H N$.

Table 5 documents the frame in the case of collusion. As mentioned, and confirmed by analysis of commentaries, (almost complete) unanimity among journalists, who regarded it as a trespass, generally occurred. However, only a few news articles and commentaries were issued on this topic, compared with the wiretapping issue.

Table 5

Frame with regard to Kaliňák - Babe (Vavrová) collusion

\begin{tabular}{||l|l|c|c|c|c|c|c|c|c|c|c|c||}
\hline & & $\mathbf{1}$ & $\mathbf{\%}$ & $\mathbf{2}$ & $\mathbf{\%}$ & $\mathbf{3}$ & $\mathbf{\%}$ & $\mathbf{4}$ & $\mathbf{\%}$ & $\mathbf{5}$ & $\mathbf{\%}$ & Total \\
\hline \multirow{3}{*}{ News articles } & Pravda & 0 & 0 & 1 & 50 & 0 & 0 & 1 & 50 & 0 & 0 & 2 \\
\cline { 2 - 12 } & SME & 0 & 0 & 0 & 0 & 0 & 0 & 2 & 100 & 0 & 0 & 2 \\
\cline { 2 - 12 } & HN & 0 & 0 & 1 & 100 & 0 & 0 & 0 & 0 & 0 & 0 & 1 \\
\hline \multirow{2}{*}{$\begin{array}{l}\text { Editorial, commen } \\
\text { tary, opinions }\end{array}$} & Pravda & 0 & 0 & 1 & 100 & 0 & 0 & 0 & 0 & 0 & 0 & 1 \\
\cline { 2 - 6 } & SME & 0 & 0 & 3 & 100 & 0 & 0 & 0 & 0 & 0 & 0 & 3 \\
\cline { 2 - 11 } & & 0 & 0 & 2 & 100 & 0 & 0 & 0 & 0 & 0 & 0 & 2 \\
\hline
\end{tabular}




\section{Conclusion: effects analysis}

The aim of this case study has been to analyse the various aspects of unethical behaviour and the double role played between the political machinery and the media. In the case of collusion described, the study has focused on the tacit political influence on media coverage.

Every journalist attempts to find and publish valuable or unique information. In cases where it is clear that the information belongs to classified materials, the secret services have the right, following court approval, to wiretap suspected individuals. The wiretapping via the MDI was thus not entirely illegal and, perhaps paradoxically, one can argue that without the wiretapping, this case of collaboration between the journalist and politician would not have become known.

All the newspapers took a mostly critical stance towards the alleged abuse of political powers (although in Galko's case it was based on unfair judgment) and journalistic rights and duties (although in the Vavrová case, she remained in journalism). This can be considered as a rare professional-ethical unity about common professional norms and values. However, a more detailed analysis revealed that the quantity of reporting about the wiretapping affair actually helped to downplay the Babe case in general, and Pravda especially produced the most articles and commentaries about the wiretapping (19), which were supported by markedly negative framing in the highest percentage of them, followed by the other two serious news outlets analysed: Sme (17) and $H N(14)$. Regarding the criterion of objectivity, Pravda was also, surprisingly, the most objective medium in reporting about the wiretapping, although the daily dropped behind in the overall verification of the articles.

As to the last question from Laswell's model (1948), „With What Effect?," it has to be noted that, interestingly enough, the investigation of the case and the overall media output, followed the scandalous journalist's vs. politician's recorded behaviour only for a certain short period of time, namely, just at the beginning while the scandal was at its peak. After that, the investigation focused mainly on the alleged illegality of the initial widespread wiretapping, which was subsequently followed by media coverage.

However, it is not surprising that the media, which may have seen the monitoring practices as especially dangerous for their journalistic rights, and, consequently, their own existence as a free media, left the scandal revolving around one of their own peers behind. The Pravda daily in par- 
ticular kept away from lengthy contemplations of the scandalous recordings and focused its attention on the surrounding wiretapping case from the very beginning.

Yet it seems that while the media focused initially on the collusion of a journalist and a politician, the media then turned their attention to the wiretapping activity and the political and/or criminal responsibility of Galko, and by and large ignored the message behind it - the possible criminal corruption cases at the MoD that Galko announced he would report to the police in short time.

In addition, more than four years after the official investigation, the media were mostly reluctant to accept, and in many cases even to inform, that the wiretapping of journalists was seen by the state authorities as legal and justified. Thus, the key root of the media-driven scandal - the alleged abuse of official powers by then MoD Galko - proved to be totally unsubstantiated. Moreover, the argument by then Prime Minister Radičová about a total ban on the wiretapping of journalists in a democracy was not supported by the official investigation. This certainly may have contributed to confusing, as it turned out, the media discourse.

The recorded conversations between Vavrová and Kaliňák did not bring any grave ethical or juridical accusations of possibly corrupt behaviour either. Strictly speaking, there were no illegal issues in their controversial phone calls and the main scandal was concerned only with the (more potential than real) unethical, unprofessional and biased attitude towards journalistic agency as an objective and impartial medium (at least in the news section). The journalist, who seemed to cooperate too closely with the politician - from a corruption perspective, it was a clear example of collusion - was criticised not only by her peers, but also by her superior. Vavrová thus played the negative role of a collaborator in this case, sending a clear message to the media about the limits of cooperation between journalists and politicians in Slovakia. However, she is still employed at the same newspaper, ${ }^{12}$ although Transparency International Slovakia refused to answer her questions in 2012 while calling her a corrupt person ${ }^{13}$ thus suggesting higher ethical standards of work for journalists are needed.

The way in which the case evolved can most likely be explained by the relatively high degree of journalist and media self-interest in defend-

12 See http://spravy.pravda.sk/autor/128-vavrova-vanda/.

13 See http://www.transparency.sk/sk/odpoved-ku-kontroverzii-o-novinarkepravdy/. 
ing their right to protect their sources and concerns about future wiretapping, and, on much smaller scale, by how collusion between a journalist and a politician influences the content of the respective media outlet (the case of Pravda). The impact of the media owner's political agenda on the media agenda could not be directly detected.

Regarding the typology of political communication culture, if this case is seen as a prevailing, or representing a more general trend - then a media-driven political communication culture dominates in the country. However, while considering this case as an exception to the rule (as all the reactions suggest), then the mixed political communication journalistic culture is more likely prevailing within Slovakia.

This case also suggests an existence of an ethical dilemma - on the one hand, a journalist needs unique sources of information. Moreover, a journalist works for a newspaper which clearly declares its political orientation. On the other hand, a too close or intimate relationship can seriously jeopardise his or her integrity, especially in news reporting. Therefore, maintaining a proper and appropriate balance (both between news and commentaries, as well as between having access to exclusive information and at the same time keeping professional-ethical integrity) is essential.

\section{References}

Butterick K. J. (2015), Complacency and Collusion: A Critical Introduction to Business and Financial Journalism, Pluto Press, London.

Davis A. (2002), Public Relations Democracy: Public Relations, Political Communications and the Mass Media in Britain, Manchester University Press, Manchester.

Entman R. (1993), Framing: Toward clarification of a fractured paradigm, „Journal of Communication", 43(49), pp. 51-58.

Lasswell H. (1948), The Structure and Function of Communication in Society. The Communication of Ideas, Institute for Religious and Social Studies, New York.

Oborne P. (2012), Is the British press really so feral?, „British Journalism Review”, 23(3), pp. 61-68.

Orme W. A. (ed.) (1997), A Culture of Collusion: An Inside Look at the Mexican Press,: Linner Rienner Publishers, Boulder, CO.

Pfetsch B. (ed.) (2013), Political Communication Cultures in Western Europe: Attitudes of Political Actors and Journalists in Nine Countries, Palgrave Macmillan, London. 
Örnebring H. (2012), Clientelism, Elites, and the Media in Central and Eastern Europe, „International Journal of Press/Politics”, 17(4), pp. 497-515.

Slovak Press Watch, Mr. THINK \& Donath-Burson-Marsteller (2008), Názory slovenských novinárov na vybrané otázky mediálneho prostredia na Slovensku. Výsledná správa z prieskumu (Opinions of Slovak Journalists on Selected Issues from the Media Environment in Slovakia), http://www.dbm.cz/ pfile/2Vysledna\%20sprava.pdf.

\section{Online news websites:}

Adam Ch. (2016, February 7), Of droids and slaves - The media in the Orbán regime, "Hungarian Free Press", http://hungarianfreepress.com/2016/02/07/of-droidsand- slaves-media-in-the-orban-regime/.

Boyd J. (2011, November 23), Prime Minister and Defence Ministry Also Tapped, http://www.thedaily.sk/prime-minister-and-defence-ministry-also-tapped/.

Bukovský M. (2011, November 24), Foto: Internetom sa šíria prepisy rozhovorov Roba s novinárkou [Photo: Transcriptions of Robo's conversations with a journalist are spreading throughout the Internet], aktuality, http://www.aktuality.sk/clanok/197635/internetom-sa-siria-prepisy-rozhovorov-roba-s-novinarkou/.

Czwitkowics T. (2011a, November 24), Smer má v Pravde údajne kontaktnú osobu [The Smer allegedly has a liason person], "Mediálne.trend", http://medialne. etrend.sk/tlac/smer-ma-v-pravde-udajne-kontaktnu-osobu.html.

Czwitkowics T. (2011b, November 25), Slišková: Konšpirácie sú smiešne [Slišková: Conspiracies are funny], "Mediálne.trend", http://medialne.etrend.sk/tlac/ sliskova-konspiracie-su-smiesne.html.

Folentová V. (2010, March 3), J\&T sl’ubuje redakcii Pravdy slobodu [J\&T promised freedom to the Pravda daily], "Sme", http://www.sme.sk/c/5267576/jt-slubuje-redakcii-pravdy-slobodu.html.

Galko L. (2011, December 3), Hry tieňového šéfredaktora Kaliňáka [Power-games of the opposition editor-in-chief Kaliňák], "blog.Sme”, http://lubomirgalko. blog.sme.sk/c/282295/Hry-tienoveho-sefredaktora-Kalinaka.html.

Galko L. (2015, September 9), Liberálny boh mi je svedkom, že nemám vel'ké uši [The Liberal God is my witness that I do not wiretap people], "blog.Sme", http://lubomirgalko.blog.sme.sk/c/387603/liberalny-boh-mi-je-svedkom-zenemam-velke-usi.html.

Glovičko J. (2011, November 23), Kaliňák hovoril redaktorke Pravdy, čo má robit' [Kaliňák was instructing Pravda's journalist about what has to be done], "Sme", http://www.sme.sk/c/6152656/kalinak-hovoril-redaktorke-pravdyco-ma-robit.html\#ixzz3gumCFDjS.

Greenwald G. (2012, August 29), Correspondence and collusion between the New York Times and the CIA, "The Guardian", http://www.theguardian.com/commentisfree/2012/aug/29/correspondence-collusion-new-york-times-cia. 
HN (2011a, November 21), Galkovi l'udia odpočúvali novinárov. Minister sa bráni [Galko's people were wiretapping journalists, The minister defends himself], "HN online", http://hn.hnonline.sk/slovensko-119/galkovi-ludia-odpocuvalinovinarov-minister-sa-brani-473904.

HN (2011b, November 22), Novinári písali o čistkách. Začali ich odpočúvat' [The journalists were writing about the clear-outs. They started to monitor them], "HN online", http://hn.hnonline.sk/slovensko-119/novinari-pisali-o-cistkachzacali-ich-odpocuvat-474043.

Kernová M. (2015. April 22), Penta si z novinárov urobila atómový kufrík [Penta has made a Nuclear Deterrence Tool of Journalists], https://dennikn.sk/blog/ penta-si-z-novinarov-urobila-atomovy-kufrik/.

Kováč P., Vargová J. (2011, November 24), Kaliňák riadi Pravdu, tvrdi Galko. On to však odmieta [Kaliňák controls Pravda, says Galko. However, he denies it], "aktuality", http://www.aktuality.sk/clanok/197646/kalinak-riadi-pravdutvrdi-galko-on-to-vsak-odmieta/.

MEMO98 (2016), Prezentácia politických predstavitel'ov a subjektov pred vol'bami do NR SR (13.2.-28.2.2016), [Presentation of Politicians and Parties during the Election Campaign to Parliament (13.2.-28.2.2016)], http://www.memo98. sk/index.php?base $=$ data/spravy/2016/1456838367.txt.

Petková Z., Kern M., Tódová M. (2011, November 21), Pravica vidí v odpočúvaní návrat Mečiara [The right wing sees the return of Mečiar in the wiretapping], "Sme", http://www.sme.sk/c/6149532/pravica-vidi-v-odpocuvani-navratmeciara.html\#ixzz3guuugFnp.

Pravda (2011a, November 22), Minister obrany Galko skončil [The Minister of Defence Galko had to leave office], "Pravda", http://spravy.pravda.sk/domace/ clanok/172461-minister-obrany-galko-skoncil/.

Pravda (2011b, November 22), Ako spravodajská služba odôvodnila odpočúvanie, pozrite si fotokópiu [What reason did the intelligence service give for wiretapping, see the photocopy], "Pravda", http://spravy.pravda.sk/domace/ clanok/172456-ako-spravodajska-sluzba-odovodnila-odpocuvanie-pozritesi-fotokopiu/.

SITA (2011, November 24), Galko vracia úder: Kaliňák priznal, že riadi Pravdu! [Galko counters: Kaliňák has admitted that he has control over Pravda!], "topky”, http://www.topky.sk/cl/100535/1292112/Galko-vracia-uder--Kalinakpriznal--ze-riadi-Pravdu-.

SITA \& TASR (2011, November 25), Galko: Dôstojník VOS odmietol ist' na detektor lži [Galko: The MDI officer refused to undergo a lie-detector test], "Sme", http://www.sme.sk/c/6155418/galko-dostojnik-vos-odmietol-ist-na-detektorlzi.html\#ixzz3gusCpomM.

Slišková N. (2011, November 20), Dennik Pravda odpočúvali Galkovi l’udia [The Pravda daily was wiretapped by Galko's people], "Pravda", http://spravy. pravda.sk/domace/clanok/172434-dennik-pravda-odpocuvali-galkovi-ludia/. 
Struhárik F. (2010, May 23), Fico už má asi vlastný denník. Denník Pravda (Fico probably owns his own daily newspaper. Daily Pravda), http://www.butlavavrba.net/2010/05/fico-uz-asi-ma-vlastny-dennik-dennik.html.

Stupňan I. (2015, April 29), Galkovi tajní sú tesne pred obžalobou [Galko's secret agents are close to being prosecuted], "Pravda", http://spravy.pravda.sk/domace/clanok/353467-galkovi-tajni-su-tesne-pre-obzalobou/?sc=art-357234.

TASR (2011a, November 24), Kalinák: Nie je podstatný rozhovor s novinárkou, ale obludnost' Galka [Kaliňák: The conversation with the journalist is not important, but the monstrosity of Galko is], "Pravda", http://spravy.pravda.sk/ domace/clanok/172494-kalinak-nie-je-podstatny-rozhovor-s-novinarkou-aleobludnost-galka/.

TASR (2011b, November 23), Zriadili špeciálny tím na prešetrenie kauzy odpočúvania, povedie ho Trnka [A special team for investigating the wiretapping case was established, Trnka will be in charge], "Pravda", http://spravy.pravda.sk/domace/clanok/172475-zriadili-specialny-tim-na-presetrenie-kauzy-odpocuvania-povedie-ho-trnka/.

TASR \& SITA (2011, November 25), Politici ku kauze „,bejby” prepisov: Kaliňák mal odstúpit' už dávno! [Politicians on the transcripts of the „babe” case: Kaliňák should have resigned a long time ago!], "topky”, http://www.topky. sk/cl/100371/1292118/Politici-ku-kauze--bejby--prepisov--Kalinak-mal-odstupit-uz-davno-.

TIS (2016, February 2), TA3 a Pravda podržali vládu aj pri štrajku učitel’ov [TA3 and Pravda hold the government line even during the teachers' strike], http:// transparency.blog.sme.sk/c/401987/ta3-a-pravda-podrzali-vladu-aj-pri-strajku-ucitelov.html. 